\title{
Pelatihan Pembuatan Pasta Bumbu Dapur di Forum Kelompok Wanita Tani Sekar Arum Tangerang Selatan
}

\author{
Tagor M. Siregar ${ }^{1}$, Lucia Soedirga ${ }^{1}$, Weny Sinaga ${ }^{1}$, Yuniwati Halim ${ }^{1}$ \\ ${ }^{1}$ Program Studi Teknologi Pangan Fakultas Sains dan Teknologi Universitas Pelita Harapan
}

tagor.siregar@uph.edu

\begin{abstract}
Abstrak
Forum kelompok wanita tani (KWT) Sekar Arum merupakan kelompok masyarakat di Tangerang Selatan yang kegiatan utamanya membudidayakan tanaman rempah-rempah dan tanaman hidroponik seperti sereh, jahe, kunyit, lengkuas, kencur dan bayam merah. Saat ini para anggota Forum KWT Sekar Arum Tangerang Selatan belum memiliki pengetahuan yang memadai tentang teknologi pengolahan pangan. Sebagai respon atas kondisi ini, Program Studi Teknologi Pangan UPH memberikan solusi berupa pelaksanaan pelatihan pembuatan pasta bumbu dapur. Kegiatan ini bertujuan agar masyarakat mampu memberdayakan bahan pangan lokal menjadi produk pangan yang dapat digunakan untuk kebutuhan sehari-hari dan bernilai ekonomi tinggi. Kegiatan ini dilakukan melalui tahap persiapan dan tahap pelaksanaan. Pada tahap persiapan dilakukan proses diskusi secara daring dengan pengurus Forum KWT Sekar Arum, proses uji coba di Laboratorium Pengolahan Pangan Program Studi Teknologi Pangan UPH dan persiapan akhir berupa pembuatan video pelatihan dan slide presentasi. Pelaksanaan pelatihan dilakukan secara webinar pada tanggal 18 Juni 2020 dan diikuti oleh 26 orang peserta. Sebagai dampak pelatihan, pembuatan pasta bumbu dapur dengan bahan pangan lokal menjadi salah satu alternatif kegiatan sehari-hari yang dilakukan oleh para anggota Forum KWTdi masa pandemi Covid 19. Pelatihan di Forum KWT Sekar Arum yang merupakan bentuk kerjasama antara Program Studi Teknologi Pangan UPH dengan Dinas Ketahanan Pangan, Pertanian dan Perikanan Kota Tangerang Selatan diharapkan dapat dilakukan secara berkala dan berkelanjutan dalam memberdayakan masyarakat.
\end{abstract}

Kata Kunci: Bawang putih, jahe, lengkuas, sereh, pasta bumbu

\section{PENDAHULUAN}

Sebagai Perguruan Tinggi Swasta, Universitas Pelita Harapan (UPH) memiliki misi yang antara lain adalah berpartisipasi secara redemtif dalam pengembangan individu dan masyarakat bagi kemuliaan Tuhan. Berdasarkan misi tersebut, maka Program Studi Teknologi Pangan UPH secara berkala melaksanakan pengabdian kepada masyarakat melalui kegiatan penyuluhan, maupun pelatihan teknologi pengolahan pangan. Pengabdian kepada Masyarakat (PkM) pada semester genap 2019/2020 ini berupa kegiatan pelatihan pembuatan bumbu dapur dalam bentuk pasta di Forum Kelompok Wanita Tani (KWT) Sekar Arum Tangerang Selatan.

Forum KWT Sekar Arum Tangerang Selatan merupakan kelompok masyarakat yang kegiatan utamanya adalah membudidayakan tanaman rempah-rempah dan tanaman hidroponik. Beberapa jenis tanaman telah dibudidayakan di sana, antara lain sereh, jahe, kunyit, lengkuas, kencur, bayam merah, dan lain-lain. Kegiatan budidaya bertujuan agar tanaman-tanaman ini kelak dapat diolah menjadi produk pangan yang bernilai ekonomi tinggi. Hingga saat ini, para anggota Forum KWT Sekar Arum Tangerang Selatan belum memiliki pengetahuan yang memadai mengenai teknologi pengolahan pangan sehingga pemanfaatan tanaman yang dibudidayakan masih sangat terbatas.

Bawang Putih, jahe, kunyit, kencur, lengkuas dan sereh merupakan jenis bahan yang diperlukan baik sebagai bumbu masak maupun bahan obatobatan (Permatasari et al., 2017). Bahan-bahan ini mudah mengalami kerusakan, terutama pada masa penyimpanan. Penyimpanan bawang putih yang baik membutuhkan ruang tersendiri dengan menjaga suhu penyimpanan untuk menghindari kerusakan umbi dan mencegah pertumbuhan tunas (Anggarini et al., 2017). Pengolahan bahan seperti bawang

$$
\text { Ekonomi, Sosial dan Budaya }
$$


putih, jahe, kunyit, kencur, lengkuas dan sereh bertujuan untuk mempertahankan mutu bahanbahan ini sebelum digunakan. Pemanfaatan bawang putih, jahe, lengkuas dan sereh masih terbatas dalam bentuk produk pengolahan seperti tepung bawang dan minyak sereh. Salah satu alternatif produk pengolahan bawang putih, jahe, lengkuas dan sereh yang belum banyak dikembangkan adalah pasta bawang putih-jahe-lengkuas dan pasta bawang putih-sereh. Pembuatan bumbu dalam bentuk pasta ini juga bertujuan agar lebih praktis saat menggunakannya dalam memasak. Pasta bawang putih-jahe-lengkuas dan pasta bawang putih-sereh juga menjadi alternatif produk sediaan bumbu. Sebagai sediaan bumbu pasta bawang putih-jahelengkuas dan pasta bawang putih-sereh harus memiliki flavor yang kuat, sehingga dapat memberikan aroma yang khas ketika digunakan (Permatasari et al., 2017). Produk pengolahan ini dapat dimanfaatkan seperti untuk menghasilkan produk makanan lainnya, menghemat biaya tenaga kerja dan waktu pengolahan tanpa harus mengupas, mencuci, dan menumbuk (Permatasari et al., 2017)

Pemanfaatan produk pengolahan ini juga sesuai dengan profil sebagian anggota forum KWT yang melakukan kegiatan UMKM (usaha mikro, kecil dan menengah) di bidang makanan, seperti warung makan yang membutuhkan sediaan bumbu berupa pasta bumbu.

Berdasarkan hal-hal yang dijelaskan di atas, maka Program Studi Teknologi Pangan UPH tergerak untuk memberikan pelatihan mengenai proses pembuatan pasta bumbu dapur yaitu pasta bawang putih-jahe-lengkuas dan pasta bawang putih-sereh. Pelaksanaan kegiatan pelatihan ini diharapkan dapat membantu Forum KWT Sekar Arum Tangerang Selatan dalam meningkatkan pemanfaatan tanaman rempah-rempah yang telah dibudidayakan, terutama tanaman jahe, lengkuas dan sereh, serta para anggota forum KWT kemudian dapat membagikan pengetahuan yang didapatkan kepada masyarakat di sekitarnya, yang akhirnya akan dapat membantu meningkatkan kehidupan ekonomi penduduk di sekitarnya.

\section{METODE}

Untuk menentukan metode pelatihan yang sesuai dengan kebutuhan Forum Kelompok Wanita Tani (KWT) Sekar Arum Tangerang Selatan, tim PkM Program Studi Teknologi Pangan UPH terlebih dahulu melakukan diskusi secara daring dengan pengurus Forum KWT Sekar Arum dan salah seorang staf Dinas Ketahanan Pangan, Pertanian dan Perikanan kota Tangerang Selatan pada bulan April 2020. Diskusi dilakukan untuk menentukan bentuk pelatihan yang sesuai dengan kebutuhan anggota Forum KWT, terutama pada masa penerapan pembatasan sosial berskala besar (PSBB) di wilayah Tangerang Raya. Kegiatan diskusi juga bertujuan menentukan jenis produk yang akan dipilih sebagai topik pelatihan pada kegiatan PkM Program Studi Teknologi Pangan UPH, berdasarkan potensi sumber daya dan kondisi masyarakat di lokasi Forum KWT Sekar Arum berada.

Setelah proses diskusi dilakukan, maka tim PkM melakukan proses uji coba di laboratorium Pengolahan Pangan Program Studi Teknologi Pangan UPH, untuk memperoleh prosedur pengolahan pengolahan dan formulasi pasta bumbu dapur berbahan dasar bawang putih, jahe, lengkuas dan sereh yang optimal.

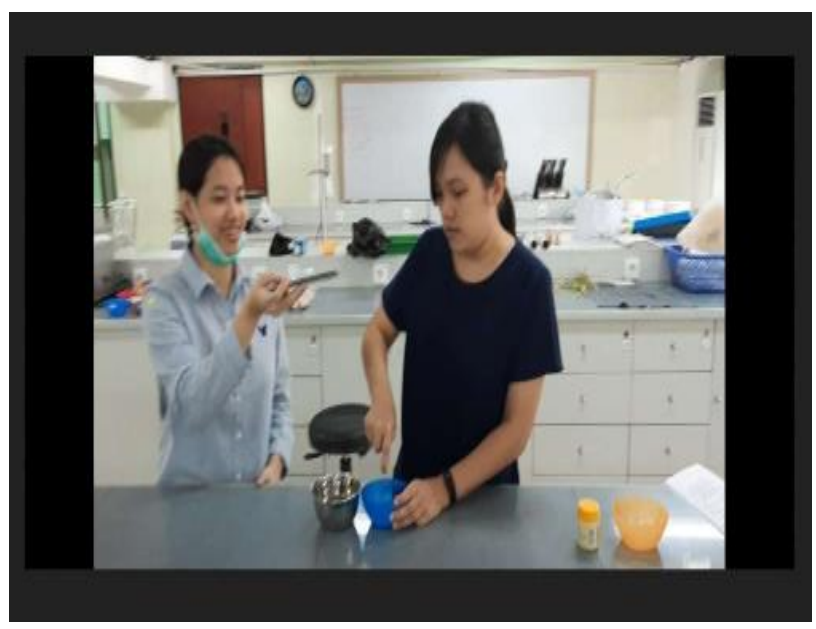

Gambar 1. Pembuatan video peragaan "Pembuatan Pasta Bumbu Dapur" di laboratorium Pengolahan Pangan Program Studi Teknologi Pangan UPH

Persiapan akhir dilakukan oleh Tim PkM, meliputi penyusunan dan pembuatan materi pelatihan berupa slide presentasi (ms-powerpoint)

Ekonomi, Sosial dan Budaya 
dan video pelatihan, menyiapkan dan menyediakan media pelatihan secara virtual (webinar) berupa akses untuk media "zoom meeting" dan "youtube" serta koordinasi dengan tim dari Forum Kelompok Wanita Tani "Sekar Arum" dan Dinas Ketahanan Pangan, Pertanian dan Perikanan kota Tangerang Selatan terkait susunan acara pelaksanaan PKM.

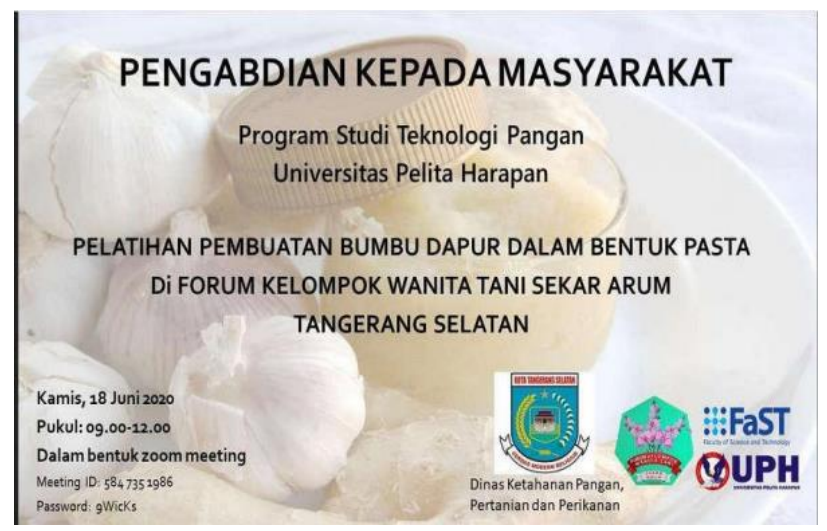

Gambar 2. Flyer kegiatan PkM Program Studi Teknologi Pangan UPH 18 Juni 2020

\section{HASIL DAN PEMBAHASAN}

\section{Profil Forum KWT Sekar Arum Tangerang Selatan}

Forum kelompok wanita tani (KWT) Sekar Arum merupakan suatu forum dimana beberapa KWT yang ada di Tangerang Selatan bergabung, seperti KWT Cemara dan KWT Dumay yang berada di wilayah Pamulang Tangerang Selatan. Setiap KWT yang tergabung dalam Forum KWT Sekar Arum memiliki kepengurusan dan kegiatan yang beragam sesuai dengan potensi dan kondisi masing-masing KWT. Secara umum kegiatan utama KWT yang ada di Tangerang Selatan adalah membudidayakan tanaman rempah-rempah dan tanaman hidroponik seperti sereh, jahe, kunyit, lengkuas, kencur, pokchoy dan bayam merah.

Dalam melaksanakan kegiatan budidaya tanaman ini, Forum KWT Sekar Arum dibina dan difasilitasi oleh Pemerintah Kota Tangerang Selatan dalam hal ini Dinas Ketahanan Pangan, Pertanian dan Perikanan.

Pada tahap persiapan, tim PkM Program Studi Teknologi Pangan UPH melakukan diskusi secara daring dengan pengurus Forum KWT Sekar Arum dan salah seorang staf Dinas Ketahanan Pangan,
Pertanian dan Perikanan kota Tangerang Selatan pada bulan April 2020. Hasil diskusi menunjukkan bahwa sebagian besar KWT yang tergabung di Forum KWT Sekar Arum melakukan budidaya tanaman rempah-rempah seperti jahe, sereh, lengkuas dan kencur pada masa penerapan pembatasan sosial berskala besar (PSBB) di wilayah Tangerang Raya. Selain itu penerapan PSBB juga mengakibatkan para anggota Forum KWT yang juga merupakan ibu rumah tangga dan pelaku UMKM (warung makan dan katering) membutuhkan ketersediaan bumbu dapur yang mencukupi, sehingga dibutuhkan sediaan bumbu dapur yang dapat disimpan dalam waktu yang cukup lama. Berdasarkan diskusi ini, maka bentuk dan topik kegiatan yang dilaksanakan adalah "Pelatihan Pembuatan Pasta Bumbu Dapur" secara webinar dengan menggunakan platform "Zoom meeting".

Kegiatan Pelatihan ini juga sejalan dengan program kerja Dinas Ketahanan Pangan, Pertanian dan Perikanan kota Tangerang Selatan pada masa pandemi Covid 19 dalam memberdayakan masyarakat di bidang pertanian khususnya yang berkaitan dengan kegiatan pasca panen. 


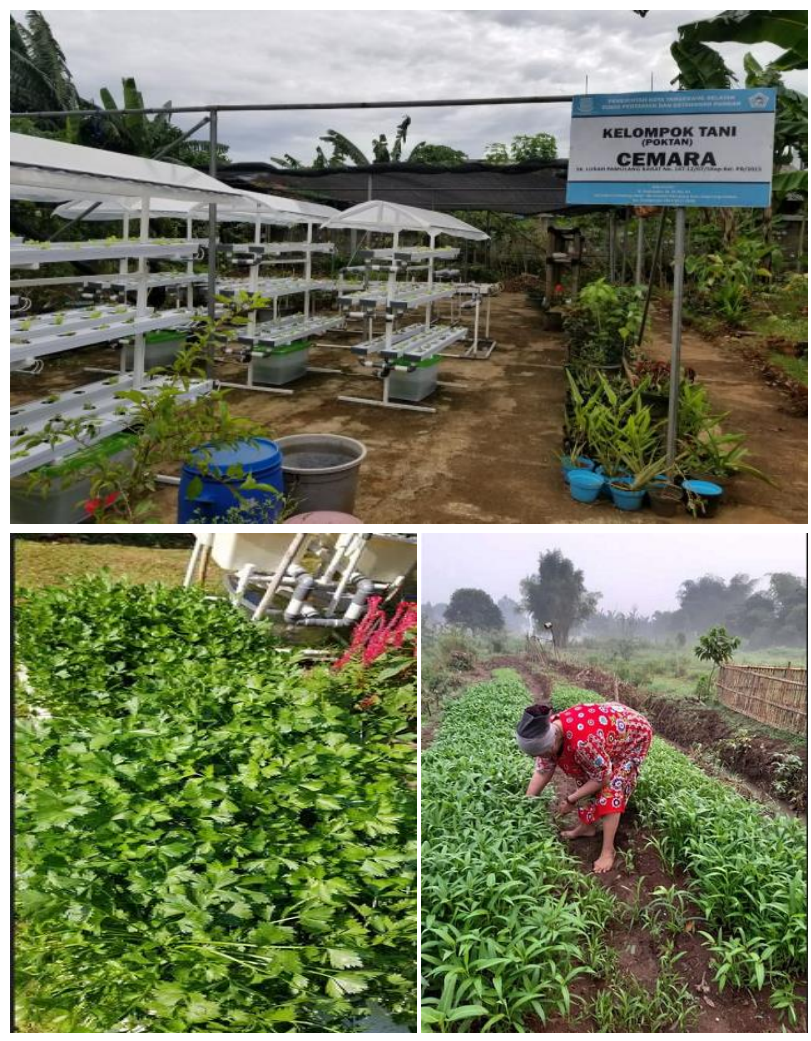

Gambar 3. Kondisi Kebun Yang dikelola salah satu KWT anggota Forum KWT Sekar Arum Tangerang Selatan

\section{Penentuan Prosedur Pengolahan dan Formulasi Optimal Pasta Bumbu Dapur}

Proses uji coba yang dilakukan di laboratorium Pengolahan Pangan Program Studi Teknologi Pangan UPH selama periode waktu mei-juni 2020 telah menghasilkan prosedur pengolahan dan formulasi optimal pasta bumbu dapur, yaitu untuk produk pasta bawang putih-jahe-lengkuas dan pasta bawang putih-sereh.

\section{Pasta Bawang Putih-Jahe-Lengkuas}

Produk ini menggunakan bahan utama bawang putih 25 siung, jahe seruas jari, dan lengkuas seruas jari. Selain bahan utama, pembuatan produk ini juga membutuhkan larutan tapioka dan larutan penstabil. Larutan tapioka merupakan campuran 2,5 sdm tepung tapioka dan 2,5 sdm air, sedangkan larutan penstabil merupakan campuran dari sejumput CMC, $1 \mathrm{sdm}$ minyak dan $2 \mathrm{sdm}$ air ( $\mathrm{sdm}=$ sendok makan; $\mathrm{CMC}=$ carboxy methyl cellulose).
Prosedur pembuatan Pasta Bawang Putih-JaheLengkuas adalah sebagai berikut: 1) Bahan-bahan utama dicampur menjadi satu dengan menggunakan blender 2) Campuran bahan-bahan utama tersebut selanjutnya ditambahkan larutan pati hingga tercampur rata dengan blender

3) Pencampuran dilanjutkan dengan dengan menambahkan larutan penstabil ke dalam blender, kemudian giling hingga halus (10-15 menit) 4) Setelah proses pencampuran, adonan pasta bawang putih-jahe-lengkuas kemudian dimasukkan ke dalam toples kaca yang sudah disterilkan sebelumnya.

5) Toples kaca yang sudah berisi pasta bawang putih-jahe-lengkuas kemudian direbus kembali selama 30 menit.

6) Setelah selesai, toples dibalik sehingga bagian atas toples juga mendapat panas yang sama.

\section{Pasta Bawang Putih-Sereh}

Produk pasta bumbu dapur ini menggunakan bahan utama bawang putih 25 siung dan sereh 10 batang. Selain bahan utama, pembuatan produk ini juga membutuhkan larutan tapioka dan larutan penstabil.

Larutan tapioka merupakan campuran 2,5 sdm tepung tapioka dan 2,5 sdm air, sedangkan larutan penstabil merupakan campuran dari sejumput CMC, $1 \mathrm{sdm}$ minyak dan $2 \mathrm{sdm}$ air ( $\mathrm{sdm}=$ sendok makan; $\mathrm{CMC}=$ carboxy methyl cellulose).Prosedur pembuatan Pasta Bawang Putih-Sereh adalah sebagai berikut: 1) Bahan-bahan utama dicampur menjadi satu dengan menggunakan blender 2) Campuran bahan-bahan utama tersebut selanjutnya ditambahkan larutan pati hingga tercampur rata dengan blender 3) Pencampuran dilanjutkan dengan dengan menambahkan larutan penstabil ke dalam blender, kemudian giling hingga halus (10-15 menit) 4) Setelah proses pencampuran, adonan pasta bawang putih-sereh kemudian dimasukkan ke dalam toples kaca yang sudah disterilkan sebelumnya.

5) Toples kaca yang sudah berisi pasta bawang putih kemudian direbus kembali selama 30 menit. 6) Setelah selesai, toples dibalik sehingga bagian atas toples juga mendapat panas yang sama.

$$
\text { Ekonomi, Sosial dan Budaya }
$$




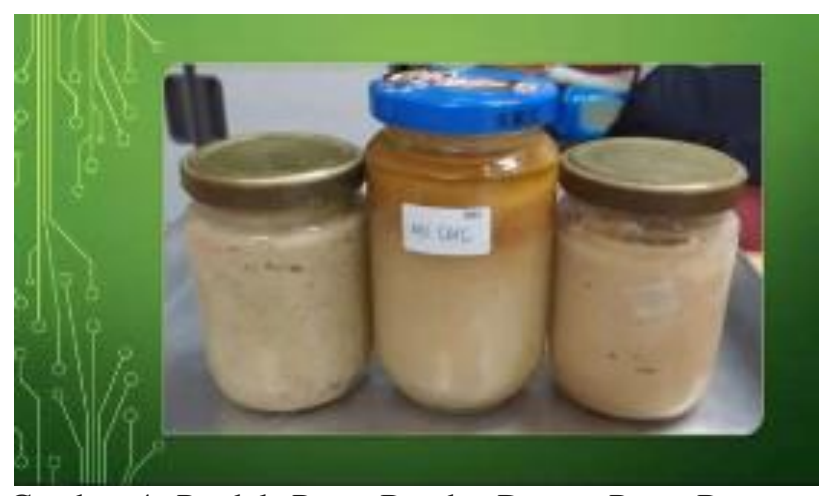

Gambar 4. Produk Pasta Bumbu Dapur; Pasta Bawang putih-jahe-lengkuas, Pasta bawang putihsereh dan Pasta bumbu dapur tanpa penstabil $\mathrm{CMC}$

Pada pembuatan pasta bumbu dapur, CMC digunakan sebagai penstabil sehingga tidak terjadi pemisahan pada produk pasta bumbu yang dihasilkan, seperti yang dapat dilihat pada gambar 4.

\section{Pelaksanaan Kegiatan Pelatihan}

Kegiatan Pengabdian kepada Masyarakat (PkM) Program Studi Teknologi Pangan Universitas Pelit Harapan dengan Forum Kelompok Wanita Tani (KWT) Sekar Arum Tangerang Selatan dilaksanakan secara virtual (webinar), oleh karena adanya kebijakan PSBB (Pembatasan Sosial Berskala Besar) di wilayah Tangerang Raya akibat adanya wabah virus Covid 19.

Kegiatan PkM melalui webinar ini dilaksanakan pada tanggal 18 Juni 2020 pada pukul 09.00 - 11.30 WIB.

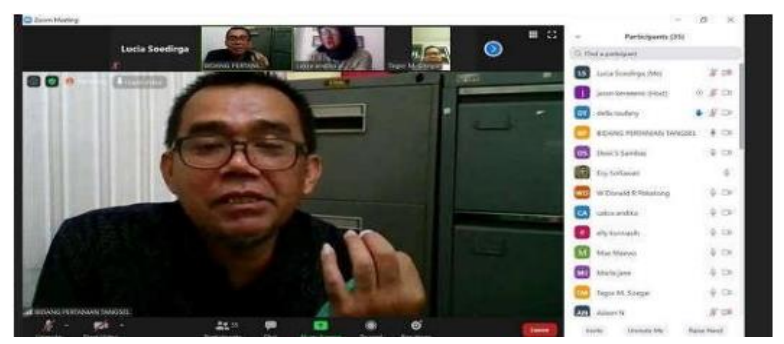

Gambar 5. Pembukaan Pelatihan oleh Kepala Bidang Pertanian dan Peternakan, Dinas Ketahanan Pangan, Pertanian dan Perikanan kota Tangerang Selatan (Ir. H.M Ramdan, MM)

Kegiatan ini diikuti oleh 26 orang peserta yang merupakan perwakilan dari setiap Kelompok Wanita
Tani (KWT) yang tergabung dalam Forum KWT Sekar Arum Tangerang Selatan. Tim pelatihan terdiri dari 4 orang dosen dan 3 orang mahasiswa Program Studi Teknologi Pangan UPH.
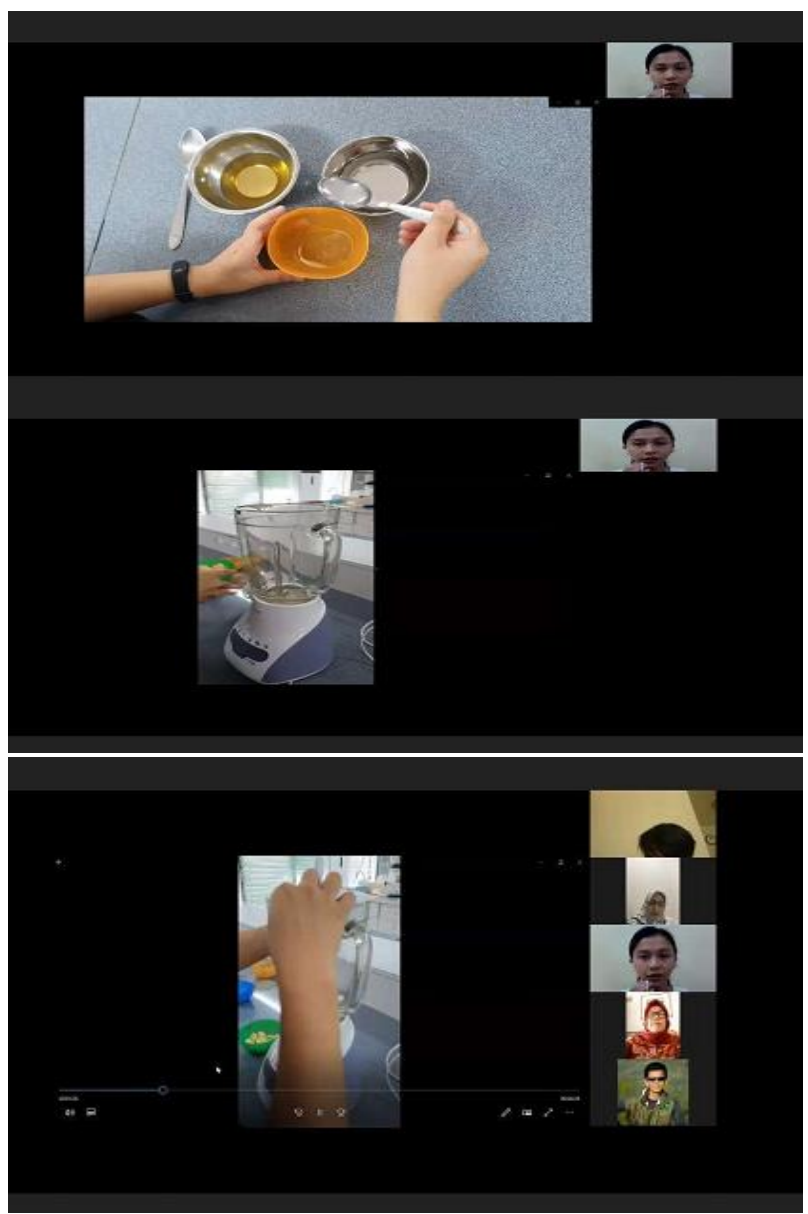

Gambar 6. Penjelasan materi pelatihan mengenai proses pembuatan pasta bumbu dapur

Kegiatan PkM berupa pelatihan pembuatan pasta bumbu dapur ini dibagi menjadi 2 sesi, yaitu presentasi dan peragaan mengenai cara pembuatan pasta bumbu dapur dan diskusi tentang bahan-bahan yang digunakan dan tahapan proses pembuatan pasta bumbu dapur. Adapun materi yang disampaikan dalam pelatihan adalah pengetahuan umum mengenai rempah-rempah, keunggulan produk pasta bumbu dapur, serta bahan-bahan yang digunakan dan cara membuat pasta bumbu dapur. Seluruh informasi ini dirangkum dalam bentuk video peragaan yang kemudian dapat diakses oleh seluruh peserta melalui media online "youtube".

Ekonomi, Sosial dan Budaya 
Setelah pemaparan materi dalam bentuk video peragaan selesai dilakukan, kegiatan diskusi dan tanya jawab langsung dilakukan untuk mengetahui respon dan pemahaman peserta mengenai pasta bumbu dapur dan proses pembuatan pasta bumbu dapur.

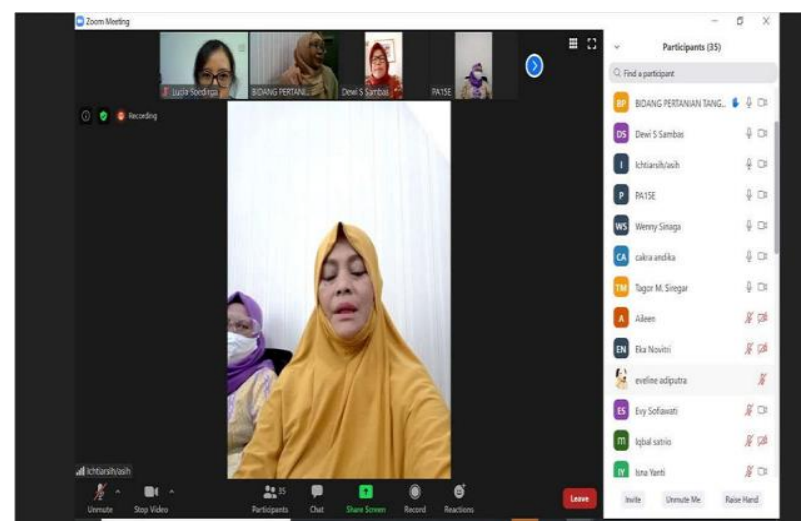

Gambar 7. Diskusi dan tanya jawab dengan peserta pelatihan mengenai proses pembuatan pasta bumbu dapur

\section{Dampak Pelatihan bagi Forum KWT Sekar Arum}

Hasil evaluasi terhadap pelaksanaan kegiatan pelatihan berdasarkan pengisian kuesioner menunjukkan bahwa peserta pelatihan memberikan respon positif terhadap pelaksanaan pelatihan di Forum KWT Sekar Arum Tangerang Selatan.

Sebanyak $34,62 \%$ peserta menyatakan bahwa kegiatan ini cukup bermanfaat dan $65,38 \%$ menyatakan bahwa kegiatan ini sangat bermanfaat. Selain itu sebanyak $38,46 \%$ peserta merasa bahwa topik yang dibawakan cukup menarik dan $61,54 \%$ merasa bahwa topik yang dibawakan sangat menarik.

Sebagian besar peserta $(80,77 \%)$ juga menyatakan bahwa kegiatan ini mudah diikuti dan media penyampaian yang digunakan juga mudah dimengerti. Hal ini menunjukkan bahwa walaupun pelatihan dilakukan secara webinar (zoom meeting) dan materi pelatihan dalam bentuk video peragaan, peserta dapat menerima dan memahami dengan baik.

Hasil evaluasi berdasarkan kuesioner ini juga menunjukkan bahwa kegiatan PkM dalam bentuk pelatihan ini dapat dilakukan lagi secara berkelanjutan, terlihat dari $96,15 \%$ peserta menginginkan adanya lagi pelatihan dengan tema yang berbeda. Hal ini menunjukkan sebagian besar peserta membutuhkan pengetahuan dan teknologi pengolahan untuk jenis tanaman lain yang dibudidayakan oleh Forum KWT Sekar Arum sehingga pada akhirnya dapat menjadi produk bernilai ekonomi tinggi. Saran yang disampaikan oleh peserta antara lain, agar ada penambahan durasi waktu pelaksanaan pelatihan.

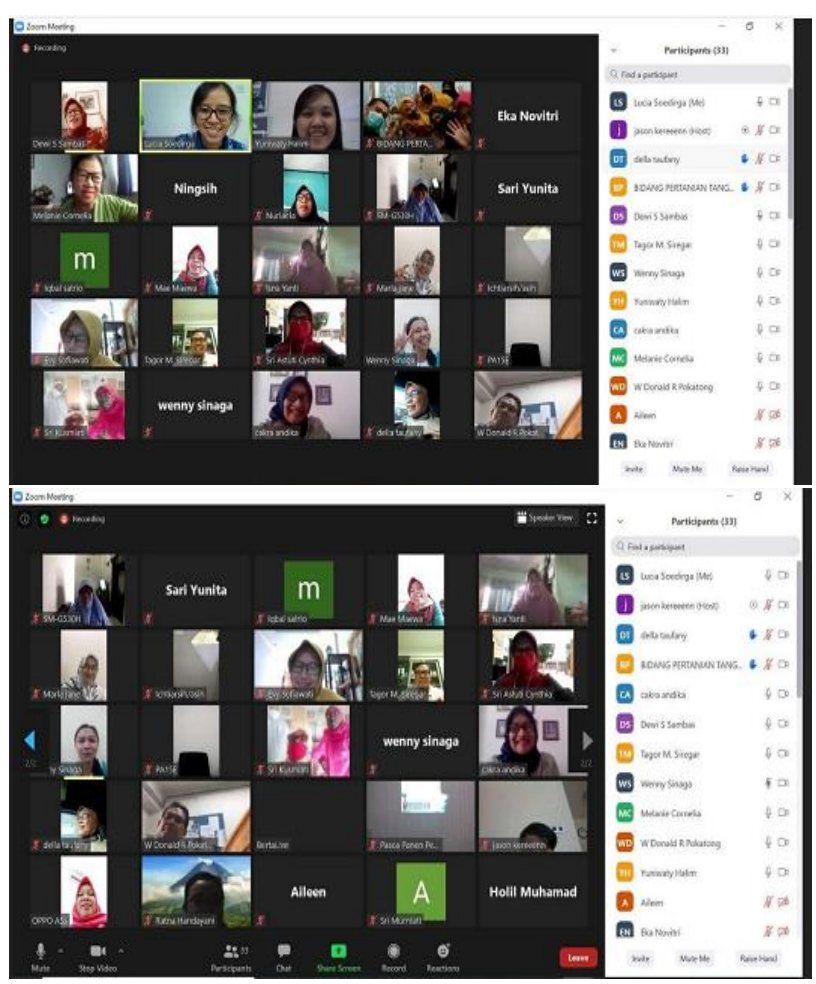

Gambar 8. Foto bersama seluruh peserta pelatihan dengan Tim PkM Program Studi Teknologi Pangan UPH

Selain melakukan evaluasi, komunikasi aktif dengan pengurus Forum KWT Sekar Arum terus dilakukan dalam mengetahui penerapan materi pelatihan yang telah disampaikan. Sebagian besar anggota Forum KWT telah menerapkan prosedur pembuatan pasta bumbu dapur dalam memenuhi kebutuhan sediaan bumbu dapur rumah tangga. Para anggota Forum KWT yang juga pelaku UMKM telah membuat pasta bumbu dapur berdasarkan materi pelatihan, yang digunakan untuk menghasilkan masakan atau produk makanan.

Ekonomi, Sosial dan Budaya

1204 
Pengurus Forum KWT juga mengemukakan bahwa pembuatan pasta bumbu dapur dengan memanfaatkan tanaman yang dibudidayakan menjadi salah satu alternatif kegiatan sehari-hari yang dilakukan oleh para anggota Forum KWT di masa pandemi Covid 19.

Berdasarkan hasil evaluasi dan komunikasi yang dilakukan dengan Forum KWT Sekar Arum dan Dinas Ketahanan Pangan, Pertanian dan Perikanan Kota Tangerang Selatan, maka kegiatan PkM dalam bentuk pelatihan ini diharapkan dapat dilakukan secara berkala dan berkelanjutan sesuai dengan potensi dan kondisi yang ada pada masyarakat sehingga pada akhirnya dapat memberdayakan masyarakat dalam pemenuhan kebutuhan pangan dan peningkatan pendapatan.

\section{KESIMPULAN}

Kegiatan PKM "Pelatihan Pembuatan Pasta Bumbu Dapur di Forum Kelompok Wanita Tani Sekar Arum Tangerang Selatan" telah dilaksanakan secara webinar pada tanggal 18 Juni 2020 dan diikuti oleh 26 orang peserta. Kegiatan pelatihan ini berupa presentasi materi pembuatan pasta bumbu dapur yaitu pasta bawang putih-jahe-lengkuas dan pasta bawang putih-sereh serta diskusi dengan peserta.

Hasil evaluasi menunjukkan materi yang disampaikan pada kegiatan pelatihan ini sangat bermanfaat dan dapat diikuti dengan baik dan mudah dimengerti oleh peserta.

Sebagai dampak pelatihan, pembuatan pasta bumbu dapur dengan memanfaatkan tanaman yang dibudidayakan menjadi salah satu alternatif kegiatan sehari-hari yang dilakukan oleh para anggota Forum KWT di masa pandemi Covid 19.

Kegiatan PkM di Forum KWT Sekar Arum yang merupakan bentuk kerjasama antara Program Studi Teknologi Pangan UPH dengan Dinas Ketahanan Pangan, Pertanian dan Perikanan Kota Tangerang Selatan diharapkan dapat dilakukan secara berkala dan berkelanjutan dalam memberdayakan masyarakat.

\section{UCAPAN TERIMAKASIH}

Penulis mengucapkan terima kasih kepada Lembaga Penelitian dan Pengabdian Masyarakat (LPPM) Universitas Pelita Harapan yang telah mendukung kegiatan Pengabdian kepada Masyarakat ini melalui skema PkM No. PM-027FaST/I/2020.

Penulis juga mengucapkan terimakasih kepada Dinas Ketahanan Pangan, Pertanian dan Perikanan kota Tangerang Selatan yang turut memfasilitasi kegiatan pelatihan ini sehingga dapat berjalan dengan baik dan lancar.

\section{REFERENSI}

Permatasari N.A, Yuliasih I dan Suryani A. (2017). Proses Pembuatan Pasta Bawang Merah (Allium cepa var. aggregatum) Dan Penentuan Umur Simpannya Dalam Kemasan Gelas. Jurnal Teknologi Industri Pertanian 27 (2). 200-208.

Anggarini S, Pamungkas ETGD dan Wignyanto (2014). Pembuatan Puree Bawang Merah Dalam Kajian Kombinasi Faktor Konsentrasi Sodium Metabisulfit Pada Proses Perendaman Dan Penambahan Maltodekstrin. Jurnal Industria vol. 3 No. 3. 138-144.

Nanik Indah S (2008). Pemanfaatan Ampas Bawang Putih Dalam Pembuatan Pasta Bawang Putih. Skripsi. Fakultas Teknologi Pertanian, Institut Pertanian Bogor.

Smith, P.G. (2011). Introduction to Food Process Engineering, $2^{\text {nd }}$ edn.Heidelberg: Springer. 